Article

\title{
Evaluating Economic Alternatives for Wood Energy Supply Based on Stochastic Simulation
}

\author{
Ulises Flores Hernández ${ }^{1, * \mathbb{C} \text {, } \text { Dirk Jaeger }^{2} \text { and Jorge Islas Samperio }}{ }^{3}$ \\ 1 Chair of Forest Operations, University of Freiburg, 79085 Freiburg im Breisgau, Germany \\ 2 Department of Forest Work Science and Engineering, University of Göttingen, 37077 Göttingen, Germany; \\ dirk.jaeger@uni-goettingen.de \\ 3 Instituto de Energías Renovables, Universidad Autónoma de México, Temixco Morelos 62580, Mexico; \\ jis@ier.unam.mx \\ * Correspondence: ulises.flores@foresteng.uni-freiburg.de; Tel.: +49-(0)761-203-3790
}

Received: 17 February 2018; Accepted: 6 April 2018; Published: 12 April 2018

\begin{abstract}
Productive forests, as a major source of biomass, represent an important pre-requisite for the development of a bio-economy. In this respect, assessments of biomass availability, efficiency of forest management, forest operations, and economic feasibility are essential. This is certainly the case for Mexico, a country with an increasing energy demand and a considerable potential for sustainable forest utilization. Hence, this paper focuses on analyzing economic alternatives for the Mexican bioenergy supply based on the costs and revenues of utilizing woody biomass residues. With a regional spatial approach, harvesting and transportation costs of utilizing selected biomass residues were stochastically calculated using Monte Carlo simulations. A sensitivity analysis of percentage variation of the most probable estimate in relation to the parameters price and cost for one alternative using net future analysis was conducted. Based on the results for the northern region, a $10 \%$ reduction of the transportation cost would reduce overall supply cost, resulting in a total revenue of $13.69 \mathrm{USD} / \mathrm{m}^{3}$ and $0.75 \mathrm{USD} / \mathrm{m}^{3}$ for harvesting residues and non-extracted stand residues, respectively. For the central south region, it is estimated that a contribution of $16.53 \mathrm{USD} / \mathrm{m}^{3}$ from 2013 and a total revenue of $33.00 \mathrm{USD} / \mathrm{m}^{3}$ in 2030 from sawmill residues will improve the value chain. The given approach and outputs provide the basis for the decision-making process regarding forest utilization towards energy generation based on economic indicators.
\end{abstract}

Keywords: bioenergy; forest woody biomass; bio-economy; Mexico

\section{Introduction}

In order to meet climate change mitigation targets, actions for reducing fossil-based products must be undertaken. As one of the most utilized energy sources worldwide and representing an estimated share of 10 to $14 \%$ of global energy supply, biomass is considered to be fundamental to accomplishing a substitution of fossil-based products table [1,2]. Based on scenario analysis at a global level, by 2050 biomass energy consumption could reach 150 EJ, where approximately $38-45 \%$ of biomass supply will come from agricultural waste and residues, and the remaining demand will be met with forest products and energy plantations [3,4]. As part of the bio-economy, bioenergy offers positive environmental and socioeconomic benefits: greenhouse gas emission reduction, employment, regional development through value chain integration, and decentralized energy systems for energy independence [5]. According to the Renewable Energy Policy Network for the 21st Century, in 2015 822,000 jobs were generated worldwide in the solid biomass sector. This included 49,000 jobs in Germany and 152,000 in the United States [6]. Regarding end-use of wood energy, thermochemical biomass conversion processes-including combustion, co-combustion, incineration, gasification, and pyrolysis-use 
biomass as solid fuel mainly to generate heat and electricity [7-10]. Due to their high efficiency and profitability, combustion and co-combustion technologies provide $90 \%$ of the global bioenergy production for commercial use [7], thereby also contributing to GHG emission reduction [4]. Thus, wood energy for heat and electricity generation contributes to fossil fuel substitution. Furthermore, forests as major biomass suppliers are of considerable importance for mitigating $\mathrm{CO}_{2}$ emissions, particularly as their role has expanded beyond timber production towards biomass production for energy generation [11]. Woody biomass in the form of wood pellets is broadly used as an energy carrier due to its ease of production and transportation [12].

Thus, for a successful transition towards a bio-economy, analyses of wood resources access, harvesting operations, silvicultural practices and business models are required. Worldwide, data on forest operations and management considering indicators of economic sustainability investments become fundamental, and this also applies to Mexico.

Mexico has a vegetation cover of approximately 138 million hectares, which represents $70.4 \%$ of the national territory. Of this, $24.2 \%$ is temperate forest and $22.8 \%$ is tropical forests [13]. From an economic perspective, based on information from the National Forestry Council (Comisión Nacional Forestal, CONAFOR), the contribution of the forestry sector to the national economy has fluctuated over time. In 1987, the sector's share of Gross Domestic Product (GDP) was 1.3\%, decreasing to $0.5 \%$ in 1996. In 1999 forest production accounted for 17,000 million MXN (Mexican peso) and its GDP share was 1.2\%. Recently, in 2014 the forestry GDP accounted to 38,065 million MXN. From 2009 to 2014, the forest industry made up an average of $0.3 \%$ of the national GDP [14]. With 21 million hectares of production forest estimated for the year 2030 [15], the potential for sustainable forest utilization in Mexico makes this resource a driving force for the development of strategies for a national bio-economy. However, the Mexican forest industry is currently stagnating due to low investment, inefficient management, inefficient harvesting systems, and poor production organization [16]. The current harvesting systems hinder higher productivities, as do inefficient transportation and chipping systems. Moreover, the lack of integration of the value chain impacts qualitative and volumetric losses of resource material for the industry, thereby also increasing costs [16]. A better understanding of the Mexican wood supply chain gained through regional case studies focusing on analyzing and evaluating biomass availability, forest management and business models is a priority for supplying and developing a regional bio-economy. To date, studies about forest biomass availability have been conducted, some of which include the cost of utilization and processing but do not consider biomass for energy use [17-19]. On the other hand, García et al. [20] calculated an energy potential of $64 \mathrm{PJ} /$ year from wood pellets burned for heat and $108 \mathrm{PJ} /$ year from traditional wood fuel for efficient cooking stoves. In a further study, Rios and Kaltschmitt [21] estimated a bioenergy potential of 638 PJ from forest and shrub woody biomass residues and 26 PJ from woody industry residues for the year 2010. Moreover, based on moderate and high scenarios, Islas et al. [22] presented a technical potential for 2004 of $71 \mathrm{PJ} /$ year from sawmill residues and harvesting residues, 997-1791 PJ/year from natural forest and 450-1246 PJ/year from plantations. An evaluation of business strategies comprising a balance of cost and price over time provides insights for decision-making processes regarding alternatives within given parameters and time horizons. Therefore, unlike these studies, the methodology developed in this research reviewed the revenues and costs of utilizing selected woody biomass sources for energy use, with a focus on the forest operations and processes needed to supply woody biomass as an input for energy transformation. It analyzed the sensitivity to changes in economic parameters given a set time horizon for utilizing forest woody biomass for energy use.

Over recent years, national timber production has fluctuated with a peak of 7 million $\mathrm{m}^{3}$ observed in 2007 [13] followed by a smooth but continuously decreasing trend. On the other hand, since 2001 an increase in national timber demand has affected the commercial and industrial balance. However, only $15 \%$ of the total national forested area is being utilized [16]. Currently, approximately $71 \%$ of the timber consumed nationally is imported [23]. With a potential for increasing forest areas under sustainable management, while decreasing timber imports, satisfying the increasing timber demand 
and enabling bioenergy supply chains; potential analysis is needed to support decision-makers in establishing an economy based on biomass resources.

Moreover, for almost eight decades, the Mexican regulatory energy framework did not allow the private sector to participate in the energy market. This was changed in 2014 with a reform of energy policy allowing private companies to be freely involved in the national energy supply. A considerable restructuring and diversification of the energy sector, together with structural changes in the rest of the economy, are expected to happen [24]. Thus, given that Mexico is an oil-producing country [25], the effect on the economy and corresponding implications for the development of alternative energy supply chains must be analyzed. Furthermore, the National Development Plan (NDP) 2006-2012 [26] included the General Law for Climate Change. This unprecedented initiative, developed by federal authorities, established for the first time that a Non-Annex I Country of the Kyoto Protocol assumes GHG reductions goals at the same level as industrialized countries [27]. Considering this, the role of energy supply chains based on forest woody biomass is of importance for the economic performance of the forest and energy sectors.

Therefore, this paper focuses on calculating economic outputs relating to alternatives for forest utilization aimed at introducing bioenergy supply chains at a regional scale. It analyzes economic alternatives for utilizing woody biomass residues for energetic use based on harvesting and sawmill operations. That is to say, based on the given costs and revenues of wood utilization, the methodology takes a regional approach in order to analyze the impact of changes to these parameters, focusing on lignocellulose biomass from forest residues as a main byproduct. Several papers assessing forest biomass supply chains present and discuss frameworks for modeling variables that estimate output in terms of biomass availability, costs and C stocks and fluxes. For instance, Sacchelli et al. [28], Schelhaas et al. [29], Sokhansanj et al. [30], Masera et al. [31] and Alemán-Nava et al. [27], among others, suggest simulation methods that incorporate variables relating to a given analysis context. For the research design, the present study takes into account these and other investigations, focusing on the costs and revenues of harvesting and sawmill operations, which are based on forest operations criteria within regional context. The selection of the included provinces, biomass sources, and time frame for this regional case study was based on limited data and data access to parameters that were fundamental inputs of the analysis. In addition to the frameworks, methods, and tools of these studies, and based on available national and regional data, this paper considers an evaluation of the Mexican forest sector with a special approach assessing the costs and revenues of potential available woody biomass for energy use.

\section{Materials and Methods}

In order to incorporate regional case studies, the research was based on the analysis of two main forested regions. These were comprised of 10 provinces representing areas with the highest timber utilization at a national scale: the north region was comprised of the provinces of Durango and Chihuahua, while the central south region included Michoacán, Oaxaca, Puebla, Veracruz, Chiapas, Guerrero, Jalisco, and the state of Mexico. This distribution was selected because the 10 mentioned provinces are representative of national round wood production rates, and because existing forest studies have analyzed the same distribution. The sources selected to account for woody biomass costs for energetic use were:

(i) Harvesting residues: this included woody biomass left on site after harvesting operations, including badly shaped logs, logs not reaching the standard diameter for transformation (between $2.5 \mathrm{~cm}$ and $12.5 \mathrm{~cm}$ diameter at breast height (DBH)), and branches with no commercial use.

(ii) Non-extracted stand residues: these were remaining stands that were marked for utilization but were not harvested according to the management plan. Only wood residues were considered from these stands since industrial round timber should preferably be used for material use first.

(iii) Sawmill residues: these included wood pieces with no commercial use after sawmill processing, in the form of cuts and strips. 
The analysis focused on cost and revenue components for the value chains of harvesting and sawmill operations, with woody biomass as an input for energy conversion. The probable and most common energy uses of wood are combustion and gasification [32], with pellets as the end product. However, economic components of the transformation technology were not included in this analysis.

According to available data on supply costs and price at a national scale, pine was selected as the main species for the assessment. In order to calculate, as described below, stochastic supply costs given the uncertainties, Monte Carlo simulations were carried out. Moreover, sensitivity analyses for evaluating alternatives with changes to parameters within a specific time series were conducted. This analysis incorporated a Net Future Value analysis (NFV) until the year 2030, with a baseline set at the year 2013. Due to the parity stability of the Mexican peso with the dollar in the year 2013, the official exchange rate on 31 December 2013 was used to convert currencies: 1.00 USD (United States Dollar) = 13.06 MXN (Mexican Peso) [33]. Moreover, based on available data and significant studies at a regional scale in the year 2013 regarding economic and forestry indicators, 2013 was set as the baseline for the analysis. Figure 1 presents a flowchart summarizing the research methodology.

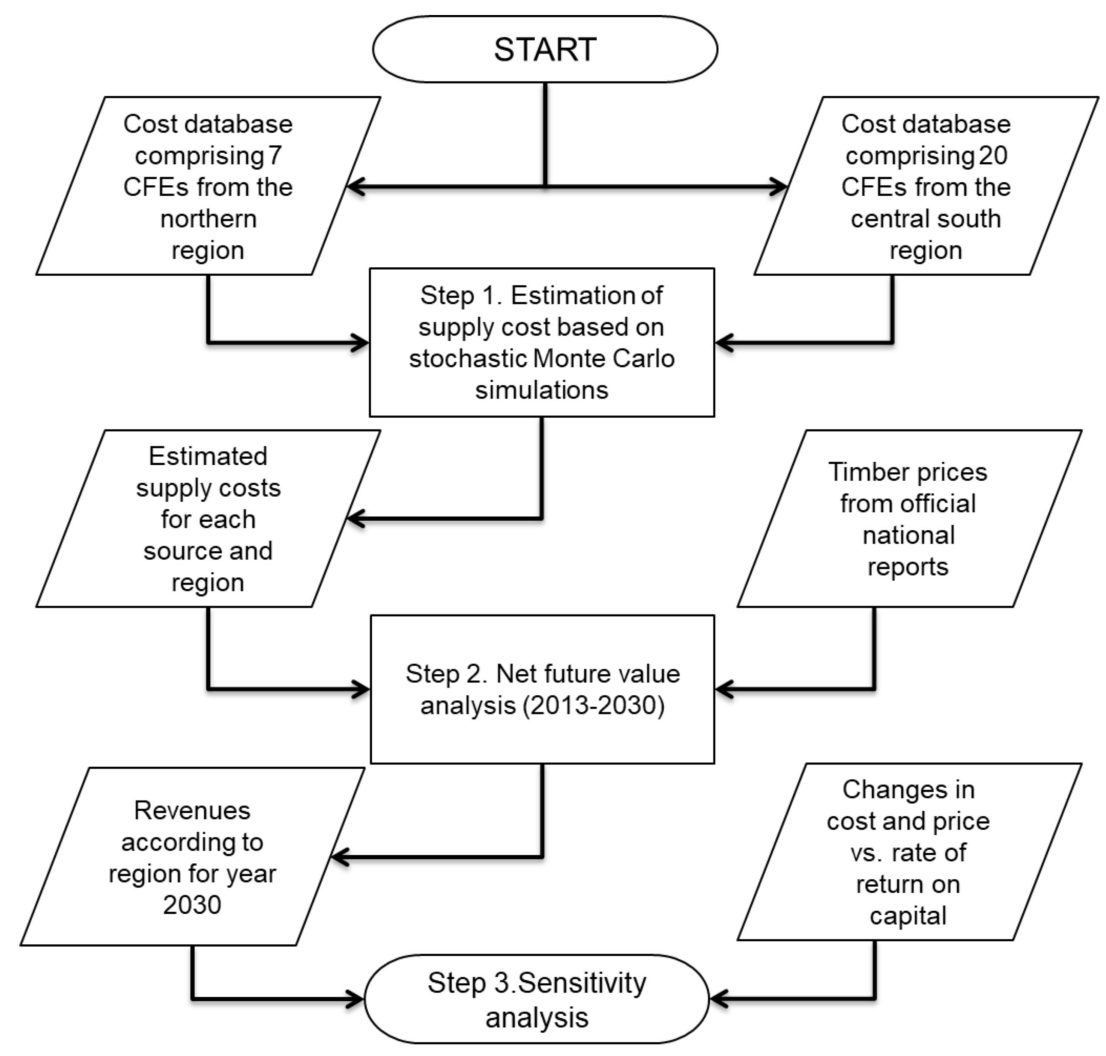

Figure 1. Flowchart of methodology summarizing processes, inputs, and outputs.

Step 1: In order to run the Monte Carlo simulations, the report "Competitiveness and market access of community forest enterprises in Mexico" (Competitividad y acceso a mercado de empresas forestales comunitarias en México) [34] developed by the World Bank and the National Forestry Council, among others, was used to estimate costs based on data from 27 community forest enterprises (CFEs), distributed across 12 provinces throughout the country. The data was organized according to northern and central south regions, resulting in seven CFEs for the north and 20 CFEs for the central south region. These costs were used as input for the stochastic simulation.

As there is no established market in Mexico for woody biomass residues, nor set prices or costs for their utilization, the costs of utilizing the analyzed residues were derived from the actual costs of round wood production. These costs included (1) labor costs; (2) labor costs from machine operation; 
(3) road maintenance and construction costs; (4) transportation costs; (5) technical support costs; (6) maintenance and depreciation from utilization; (7) operation and maintenance costs from sawmill processing; and (8) depreciation from sawmill operation (Table 1).

In order to calculate the cost of utilizing woody biomass for the three biomass sources, the mentioned costs were allocated as presented in Table 1.

As shown in Table 1, there were differences in the allocation of costs for each biomass source. This was based on the assumption that the analyzed value chains, harvesting and sawmill value chains, are integrated within the same group of stakeholders and actors. That is to say, the harvesting and extraction process for both products (whole stem and residues) is carried out by the same CFE along the value chain, so that the CFE absorbs regular costs plus the costs included for biomass supply for energy uses. The related costs of utilizing biomass for energy use presented in Table 1 were considered as extra costs for the CFE. Therefore, given that non-extracted stands involve an extra investment, higher costs are related to this source. The assumptions and framework boundaries for the present analysis are outlined below:

(a) The integration of the harvesting processes and sawmill operation along the value chain is optimal so that the CFE operates as a single entity. No external companies, stakeholders, or actors participate in utilizing forest woody biomass for energy use from harvesting and sawmill operation.

(b) For the two analyzed value chains, harvesting and sawmill value chain, the CFE absorbs costs together with the extra supply costs related to biomass for energy. Biomass for energy use and its related supply costs and revenues are a plus for the CFE.

(c) The supply costs included in the analysis (Table 1) were referred only to account woody biomass for energy use coming from the selected three sources. The economic output from utilization of industrial round wood in addition to harvesting residues for energy was not presented. No industrial round wood was considered.

(d) Equal prices for industrial round timber and woody biomass in the short- to mid-term were assumed. A weighted price was derived from industrial round timber prices.

(e) The presented analysis considered an interest rate of $5 \%$ to be conservative. Usually an interest rate of $12 \%$ is used in Mexico for assessing public investment projects. When mid-term time frames are set for analysis, lower interest rates such as that used in this paper are recommended. If higher investment returns are required in the short term, high interest rates are used.

(f) In order to simulate economic outputs for the sawmill residues, an allocation of supply costs and revenues based on a coefficient from sawmill residues was applied [17]. This coefficient represented the available biomass as residues in cubic meters from sawmill operations, amounting to a value of 0.41 [17]. Revenues and costs from sawmill residues were assumed to have this share when accounting for biomass for energy use as a byproduct. Thus, to allocate weighted values, resulting supply costs and revenues were multiplied by the coefficient from sawmill residues.

(g) Supply costs were assumed to be stable during short- and mid-term assessments.

(h) Framework boundaries comprised only forest woody biomass for energy as the end product in the analysis. An economic analysis beyond this point, for example technology for energy conversion, was not undertaken.

Furthermore, each cost was set to be independent from others, that is to say, its statistical distribution does not affect any other variable value. All variables were considered to be independent. Table 2 presents a summary of the cost samples for each region involving maximum and minimum values, range, standard deviation and mean. These parameters are based on data from [34]. 
Table 1. Allocated costs according to source and definition.

\begin{tabular}{|c|c|c|}
\hline Biomass Source & Cost & Definition \\
\hline \multirow{4}{*}{ (i) Harvesting residues } & (1) Labor cost & \multirow{2}{*}{$\begin{array}{l}\text { These two costs were referred to operation costs from workforce. Based on the database and information } \\
\text { from [34], labor costs were used as a separate cost element but additional to labor costs of machine operation }\end{array}$} \\
\hline & (2) Labor cost of machine operation & \\
\hline & (4) Transportation cost & $\begin{array}{l}\text { Here a weighted transportation cost based on transported volumes, species and quality was considered. } \\
\text { Averages distances were also taken into account [34] }\end{array}$ \\
\hline & (6) Maintenance costs and depreciation from utilization & $\begin{array}{l}\text { This represented the capital costs as the sum of depreciation and maintenance costs Depreciation was } \\
\text { calculated using a } 5 \text { year useful life and the straight line method [34] }\end{array}$ \\
\hline \multirow{6}{*}{ (ii) Non extracted stand residues } & (1) Labor cost & \multirow{2}{*}{$\begin{array}{l}\text { These two costs were referred to operation costs from workforce. Based on the database and information } \\
\text { from [34], labor costs were used as a separate cost element but additional to labor costs of machine operation }\end{array}$} \\
\hline & (2) Labor cost of machine operation & \\
\hline & (3) Road maintenance and construction costs & $\begin{array}{l}\text { Considered as a management costs, road maintenance and construction costs were grouped with this source } \\
\text { given the investment necessary to make biomass from non-extracted stands available }\end{array}$ \\
\hline & (4) Transportation cost & $\begin{array}{l}\text { Here a weighted transportation cost based on transported volumes, species and quality was considered. } \\
\text { Averages distances were also taken into account [34] }\end{array}$ \\
\hline & (5) Technical support cost & $\begin{array}{l}\text { This cost involved technical services and consultancy as well as other extra support for the community } \\
\text { forest enterprises [34] }\end{array}$ \\
\hline & (6) Maintenance costs and depreciation from utilization & $\begin{array}{l}\text { This represented the capital costs as the sum of the depreciation and maintenance costs. Depreciation was } \\
\text { calculated using a } 5 \text { year useful life and the straight line method [34] }\end{array}$ \\
\hline \multirow{2}{*}{ (iii) Sawmill residues } & (7) Operation and maintenance costs of sawmill processing & These included the costs of machine operation and the cost of maintaining machines for the sawmill process \\
\hline & (8) Depreciation of sawmill operation & This was considered to be the capital cost of sawmill operation \\
\hline
\end{tabular}

Table 2. Statistical parameters from sampled data according to cost and region.

\begin{tabular}{|c|c|c|c|c|c|c|c|c|}
\hline & Labor Cost & $\begin{array}{l}\text { Labor Cost from } \\
\text { Machine op. }\end{array}$ & $\begin{array}{l}\text { Road Maintenance and } \\
\text { Construction Cost }\end{array}$ & $\begin{array}{l}\text { Transportation } \\
\text { Cost }\end{array}$ & $\begin{array}{c}\text { Technical Support } \\
\text { Cost }\end{array}$ & $\begin{array}{c}\text { Maintenance and } \\
\text { Depreciation from ut. }\end{array}$ & $\begin{array}{c}\text { Operation and } \\
\text { Maintenance Cost SW }\end{array}$ & Depreciation SW \\
\hline North & $\mathrm{USD} / \mathrm{m}^{3}$ & $\mathrm{USD} / \mathrm{m}^{3}$ & $\mathrm{USD} / \mathrm{m}^{3}$ & $\mathrm{USD} / \mathrm{m}^{3}$ & $\mathrm{USD} / \mathrm{m}^{3}$ & $\mathrm{USD} / \mathrm{m}^{3}$ & $\mathrm{USD} / \mathrm{m}^{3}$ & $\mathrm{USD} / \mathrm{m}^{3}$ \\
\hline Min & 0.69 & 2.14 & 0.08 & 6.66 & 0.92 & 1.23 & 5.21 & 3.91 \\
\hline Max & 16.16 & 18.76 & 6.66 & 24.27 & 4.75 & 18.07 & 31.24 & 7.73 \\
\hline Range & 15.47 & 16.62 & 6.58 & 17.61 & 3.83 & 16.85 & 26.03 & 3.83 \\
\hline Standard deviation & 5.26 & 6.32 & 2.26 & 6.68 & 1.55 & 5.73 & 11.69 & 2.01 \\
\hline Mean & 4.98 & 12.44 & 1.68 & 13.05 & 3.08 & 5.72 & 14.58 & 5.50 \\
\hline \multicolumn{9}{|l|}{ Central South } \\
\hline $\operatorname{Max}$ & 91.04 & 41.81 & 5.67 & 44.10 & 18.61 & 39.74 & 94.18 & 16.85 \\
\hline Range & 88.97 & 41.73 & 5.67 & 37.98 & 18.53 & 39.36 & 92.80 & 15.77 \\
\hline Standard deviation & 20.03 & 11.87 & 1.65 & 8.63 & 5.16 & 10.69 & 22.60 & 4.95 \\
\hline Mean & 17.06 & 11.81 & 2.08 & 18.45 & 5.98 & 11.47 & 14.48 & 7.88 \\
\hline
\end{tabular}


Table 2 presents the variability in costs for each region mainly due to the variations on the harvesting levels between CFEs and regions, the efficiency of each CFE and updated data from the sampled CFEs among others [34]. Thus, a method to treat uncertainties and variability was used.

Giving statistical sampling to represent uncertainties by specifying inputs as probabilistic distributions, associated costs of utilizing available woody biomass for energetic use were estimated using the Monte Carlo method. This method uses aleatory generated values to model and simulate processes in order to estimate complex outputs. Monte Carlo simulation accounts for uncertainties in the data and assumptions. That is to say, random samples are considered from assumed distributions of an uncertain parameter, to make estimations for each set of random values. The procedure is carried out as many times as is necessary for the changes in the sample means and variances to converge within the desired tolerances [35]. For this regional case study, the identified uncertainties revealed differences between the economic performance of the forest sector in the northern and central south regions, as well as other parameters such as transportation distances, infrastructure, and market development. For the Monte Carlo simulations, assuming that the most probable value will occur between a minimum and maximum number with the same probability, a uniform distribution was used for all analyzed costs within the northern region. For the central south region, information about maximum, minimum, and most commonly occurring values for the transportation cost was available. Therefore, a triangular probability function was used.

Monte Carlo analysis provided an estimate of the expected value of a random variable according to a number of iterations [36]. In order to estimate the number of iterations, the standard deviation and the error were estimated. Equation (1) gave the total error of the estimation. The number of iteration was calculated based on the standard deviation of the minimum and maximum values and its averages and an absolute error of $2 \%$ (Equation (2)). A gross estimate of the expected value is the average of the minimum and maximum values:

$$
\begin{gathered}
\varepsilon=\frac{3 \sigma}{\sqrt{N}} \\
N=\left[\frac{3 \sigma}{\varepsilon}\right]^{2},
\end{gathered}
$$

where $\varepsilon$ is the error of the estimate and $N$ the number of iterations. After the number of iterations was defined, the simulations were run. A confidence interval of $95 \%$ was set for estimating the expected total cost. Then, the mean, standard deviation, minimum, maximum, range, and the standard error as key parameters were estimated for each cost as the output of the Monte Carlo analysis. The expected value of the random variable was the mean of the total involved cost generated from the results after simulating. For the northern region, the costs of utilizing the harvesting residues were simulated according to 8580 iterations. A total of 8815 iterations for the cost of utilizing the non-extracted stand residues were carried out. A total of 8677 iterations for the costs associated with utilizing sawmill residues were run. For the central south region, iteration values of 18,214, 18,626 and 17,017 used respectively. All simulations had 100 repetitions.

Once the expected value from each cost was estimated using Monte Carlo simulation, the relevant supply costs for each of the three woody biomass sources-(i) harvesting residues (labor cost, labor cost of machine operation, transportation cost, maintenance costs and depreciation from utilization); (ii) non-extracted stand residues (labor cost, labor cost of machine operation, road maintenance and construction costs, transportation cost, technical support cost, maintenance costs, and depreciation from utilization); and (iii) sawmill residues (operation and maintenance costs from sawmill processing and depreciation from sawmill operation) - were analyzed and summed.

Step 2: After calculating the values using stochastic simulation, an estimation of cash flows given revenues based on supply costs and net future value analysis (NFV) was conducted. Considering 2013 as the baseline year, timber prices were taken from the trimestral report October December 2013 developed by CONAFOR from its pricing system for timber forest products (Sistema de precios de productos forestales maderables (SIPRE)) [14]. Due to limited data between provinces and regions, 
the timber price of pine, as the most utilized species in Mexico, was used for calculating revenues of the three biomass sources. An NFV of alternatives was then performed. An interest rate of $5 \%$ was used to evaluate the differences relating to the economic parameters for 17 years (2013-2030). A future value (FV); commonly known as a measure of value; is a numerically defined attribute used in an NFV as a selection criteria for decision-making [36]. Using methods from engineering economy, Equation (3) allows for the calculation of the future amount of money based on interest rate, present amount of money and number of analyzed periods:

$$
F_{i j}=P_{i j}(1+i \%)^{n}-C_{i j}(1+i \%)^{n}=P_{i j}(F / P, i \%, n)-C_{i j}(F / P, i \%, n),
$$

where $F$ is the total future amount of money, $P$ is the timber price and $C$ is the supply cost according to $i$ region and the $j$ analyzed source (harvesting residues, non-extracted stands residues and sawmill residues), $i \%$ is the interest rate and $n$ is the number of analyzed periods. The fundamental factor in engineering economy determines the amount of money that accumulates after $n$ years or periods from a present value with compound interest once a year or period. The factor $(1+i \%)^{n}$ is defined as the single payment compound amount, which is generally referred to as the factor $\mathrm{F} / \mathrm{P}$, also known as the future given present factor [36].

Step 3: Afterwards, using the resulting outputs from the NFV, a sensitivity analysis was carried out. A sensitivity analysis determines the weight of an alteration over a measure of value, for instances future value, and an alternative when a specific parameter varies within a range of values [36]. In this paper, a variation in the parameters cost and price was evaluated using the future value (FV) as the measure of value. The time horizon of the evaluation was 17 years (2013-2030). Furthermore, the sensitivity analysis of the percentage variation when changing the rate of return of capital (ROC) was presented. The range in variation of the ROC for this analysis was $-20 \%$ to $20 \%$. The ROC was defined as the earned rate over the unrecovered balance of an investment, so that the payment or final entry equals the balance of exactly zero using the considered interest [36]. The purpose was to evaluate the sensitivity of the chosen parameters against the ROC in a clearer way. Values calculated with the Monte Carlo simulations were used considering the economic flow when timber prices and supply costs are related. The analysis was developed for the three analyzed biomass sources for both regions. The sensitivity analysis considered the flow calculation over time in order to estimate the revenues as part of the results. With the given results, an evaluation of one alternative with changes to several parameters within a specific time series can be graphically developed, representing a transparent decision-making process.

\section{Results}

Tables 3 and 4 show results from statistical parameters of the Monte Carlo simulations for costs of each of the three selected sources by region. For the northern region, results showed a total cost of $43.98 \mathrm{USD} / \mathrm{m}^{3}$ for utilizing harvesting residues, $50.25 \mathrm{USD} / \mathrm{m}^{3}$ for non-extracted stand residues and $24.11 \mathrm{USD} / \mathrm{m}^{3}$ for sawmill residues. Using a triangular probabilistic function for transportation costs within the central south region, the harvesting costs amounted to $85.32 \mathrm{USD} / \mathrm{m}^{3}$ while cost for utilizing non-extracted stand residues amounted to $97.86 \mathrm{USD} / \mathrm{m}^{3}$. The utilization cost of sawmill residues resulted in $18.11 \mathrm{USD} / \mathrm{m}^{3}$.

All the supply costs were higher in the central south region, with the exception of operation and maintenance costs of sawmill processing. Values were affected by the number of samples taken per region according to their variability. As mentioned in the assumptions, a factor of 0.41 multiplied the parameters supply costs and timber prices for the sawmill residues, resulting in the values presented in Table 5.

Afterwards, an analysis was carried out to evaluate the impact of the economic flow when changes to prices, cost and the rate of return on capital (ROC) occur. In order to do so, a sensitivity analysis considering two parameters (price and cost) for one alternative using net future analysis as the measure 
of the value, was developed. Therefore, resulting costs from Monte Carlo simulations together with timber prices from official reports were used to develop a net future value analysis (Table 5).

Table 3. Monte Carlo simulation results according to cost for the northern region (USD $/ \mathrm{m}^{3}$ ).

\begin{tabular}{cccc}
\hline & Harvesting Residues & Non-Extracted Stand Residues & Sawmill Residues \\
\hline Min & 14.44 & 18.00 & 9.35 \\
Max & 74.65 & 83.58 & 38.93 \\
Mean & 43.98 & 50.25 & 24.11 \\
Standard dev. & 9.76 & 9.88 & 7.61 \\
CI of 95\% & $43.77 \leq \mathrm{X} \leq 44.18$ & $50.04 \leq \mathrm{X} \leq 50.45$ & $23.95 \leq \mathrm{X} \leq 24.27$ \\
Range & 60.21 & 65.58 & 29.58 \\
Standard error & $0.72 \%$ & $0.63 \%$ & $1.02 \%$ \\
Number of simulations $(\mathrm{N})$ & 8580 & 8815 & 8677 \\
\hline
\end{tabular}

Table 4. Monte Carlo simulation results according to cost for the central south region (USD $\left./ \mathrm{m}^{3}\right)$.

\begin{tabular}{cccc}
\hline & Harvesting Residues & Non-Extracted Stand Residues & Sawmill Residues \\
\hline Min & 16.63 & 25.92 & 2.66 \\
Max & 155.93 & 168.24 & 35.07 \\
Mean & 85.32 & 97.86 & 18.81 \\
Standard dev. & 21.09 & 21.78 & 6.71 \\
CI of 95\% & $85.01 \leq \mathrm{X} \leq 85.62$ & $97.54 \leq \mathrm{X} \leq 98.16$ & $18.91 \leq \mathrm{X} \leq 18.71$ \\
Range & 139.30 & 142.31 & 32.40 \\
Standard error & $0.55 \%$ & $0.49 \%$ & $0.82 \%$ \\
Number of simulations $(\mathrm{N})$ & 18,214 & 18,626 & 17,017 \\
\hline
\end{tabular}

Table 5. Timber prices and supply costs involved for calculating NFV of alternatives based on the year 2013 as the status quo $\left(\mathrm{USD} / \mathrm{m}^{3}\right)$.

\begin{tabular}{cccc}
\hline & Harvesting Residues & Non-Extracted Stands Residues & Sawmill Residues \\
\hline Timber price & & & \\
\hline North & 45.55 & 45.55 & 24.28 \\
Central South & 35.00 & 35.00 & 24.24 \\
\hline Supply cost & & & \\
\hline North & 43.98 & 50.25 & 9.89 \\
Central South & 85.32 & 97.86 & 7.71 \\
\hline
\end{tabular}

Using these values as inputs, the resulting revenue values within a period of 17 years were analyzed against changes in price and cost together with their impact on ROC. The sensitivity analysis consisted of evaluating changes to ROC when the parameters timber price and supply cost were increased or decreased within a range of $-40 \%$ to $40 \%$. Table 6 presents results for revenue and ROC when the parameter price is changed within the mentioned range. In contrast, Table 7 shows values for revenue and ROC when the parameter cost varies.

For the northern region, results are summarized in Figure 2 with a graph showing the percentage change of each parameter against the measure of the value. The variation of each parameter was represented as a percentage deviation of the most probable estimate in the horizontal axis. If the response curve of the ROC is flat and is close to the horizontal axis within the total variation range for one parameter, the ROC has low sensitivity to the changes in the analyzed parameter.

Based on Figure 2, the parameters harvesting residues cost and non-extracted stand residues cost showed considerable sensitivity to changes in ROC, some at higher values than others. With respect to prices, all three biomass sources showed sensitivity to the ROC, especially the harvesting residues price, where, for instance, an increment of $10 \%$ in the estimated harvesting residues price will increase the ROC to $14 \%$. Furthermore, based on calculations, results pointed out similar sensitivity to the parameter price and the parameter cost for the northern region. According to the analysis, for the analyzed time frame, setting prices $10 \%$ higher than that observed as the status quo will result on an 
ROC of at least $6 \%$. This means that a yield rate of at least $6 \%$ given the observed time frame will result in revenues between $14.05 \mathrm{USD} / \mathrm{m}^{3}$ and $94.06 \mathrm{USD} / \mathrm{m}^{3}$ (see Table 6). This was based on status quo conditions from the year 2013, where only $15 \%$ of the total forested area was utilized [14] and a high dependency on imports was observed. Moreover, the results showed that ROC has a considerable sensitivity to changes to the parameter price for the three sources. That is to say, when developing bioenergy markets utilizing forest woody residues, strategies focused on price increase will have a strong impact. Within a range of $-40 \%$ to $40 \%$ on the analyzed parameters, most of the ROC output values were distributed within a range of $-20 \%$ to $20 \%$, resulting in a higher margin of contribution for changes in the parameter price for the three analyzed biomass sources. Additionally, for the parameter price of the harvesting residues, the highest expected value was $45.37 \mathrm{USD} / \mathrm{m}^{3}$, compared to 43.93 $\mathrm{USD} / \mathrm{m}^{3}$ for the parameter cost. This corresponds to ROCs of $21.86 \%$ and $21.63 \%$ respectively (see Table 8).

Table 6. Sensitivity analysis for the parameter timber price according to sources and regions (2030).

\begin{tabular}{|c|c|c|c|c|c|c|}
\hline \multicolumn{7}{|c|}{ Northern Region } \\
\hline & \multicolumn{2}{|c|}{ Harvesting Residues } & \multicolumn{2}{|c|}{ Non-Extracted Stand Residues } & \multicolumn{2}{|c|}{ Sawmill Residues } \\
\hline $\begin{array}{c}\text { Change in Timber } \\
\text { Price }(\%)\end{array}$ & $\begin{array}{l}\text { Revenue } \\
\text { (USD/m³) }\end{array}$ & ROC & $\begin{array}{l}\text { Revenue } \\
\left(\mathrm{USD} / \mathrm{m}^{3}\right)\end{array}$ & ROC & $\begin{array}{l}\text { Revenue } \\
\left(\mathrm{USD} / \mathrm{m}^{3} \text { ) }\right.\end{array}$ & ROC \\
\hline-40 & -38.15 & $-221 \%$ & -52.53 & $-212 \%$ & 10.74 & $-2 \%$ \\
\hline-30 & -27.71 & $-218 \%$ & -42.08 & $-209 \%$ & 16.30 & $1 \%$ \\
\hline-20 & -17.27 & $-215 \%$ & -31.64 & $-205 \%$ & 21.87 & $2 \%$ \\
\hline-10 & -6.83 & $-209 \%$ & -21.20 & $-15 \%$ & 27.43 & $4 \%$ \\
\hline 0 & 3.61 & $5 \%$ & -10.76 & $5 \%$ & 33.00 & $5 \%$ \\
\hline 10 & 14.05 & $14 \%$ & -0.32 & $9 \%$ & 38.56 & $6 \%$ \\
\hline 20 & 24.49 & $18 \%$ & 10.12 & $12 \%$ & 44.13 & $7 \%$ \\
\hline 30 & 34.93 & $20 \%$ & 20.56 & $14 \%$ & 49.69 & $8 \%$ \\
\hline 40 & 45.37 & $22 \%$ & 31.00 & $15 \%$ & 55.26 & $8 \%$ \\
\hline \multicolumn{7}{|c|}{ Central South Region } \\
\hline-40 & -147.43 & $3 \%$ & -176.15 & $3 \%$ & 15.65 & $0 \%$ \\
\hline-30 & -139.40 & $4 \%$ & -168.13 & $4 \%$ & 21.20 & $1 \%$ \\
\hline-20 & -131.38 & $4 \%$ & -160.11 & $4 \%$ & 26.76 & $3 \%$ \\
\hline-10 & -123.36 & $5 \%$ & -152.09 & $5 \%$ & 32.31 & $4 \%$ \\
\hline 0 & -115.34 & $5 \%$ & -144.06 & $5 \%$ & 37.87 & $5 \%$ \\
\hline 10 & -107.32 & $5 \%$ & -136.04 & $5 \%$ & 43.42 & $6 \%$ \\
\hline 20 & -99.29 & $6 \%$ & -128.02 & $6 \%$ & 48.98 & $7 \%$ \\
\hline 30 & -91.27 & $6 \%$ & -120.00 & $6 \%$ & 54.53 & $7 \%$ \\
\hline 40 & -83.25 & $7 \%$ & -111.98 & $6 \%$ & 60.09 & $8 \%$ \\
\hline
\end{tabular}

Table 7. Sensitivity analysis for the parameter supply cost according to sources and regions (2030).

\begin{tabular}{|c|c|c|c|c|c|c|}
\hline \multicolumn{7}{|c|}{ Northern Region } \\
\hline & \multicolumn{2}{|c|}{ Harvesting Residues } & \multicolumn{2}{|c|}{ Non-Extracted Stand Residues } & \multicolumn{2}{|c|}{ Sawmill Residues } \\
\hline $\begin{array}{l}\text { Change in Supply } \\
\text { Cost }(\%)\end{array}$ & $\begin{array}{l}\text { Revenue } \\
\left(\mathrm{USD} / \mathrm{m}^{3}\right)\end{array}$ & ROC & $\begin{array}{c}\text { Revenue } \\
\left(\mathrm{USD} / \mathrm{m}^{3}\right)\end{array}$ & ROC & $\begin{array}{l}\text { Revenue } \\
\left(\mathrm{USD} / \mathrm{m}^{3}\right)\end{array}$ & ROC \\
\hline-40 & 43.93 & $22 \%$ & 35.30 & $16 \%$ & 42.06 & $7 \%$ \\
\hline-30 & 33.85 & $20 \%$ & 23.79 & $14 \%$ & 39.80 & $6 \%$ \\
\hline-20 & 23.77 & $17 \%$ & 12.27 & $12 \%$ & 37.53 & $6 \%$ \\
\hline-10 & 13.69 & $14 \%$ & 0.75 & $10 \%$ & 35.26 & $5 \%$ \\
\hline 0 & 3.61 & $5 \%$ & -10.76 & $5 \%$ & 33.00 & $5 \%$ \\
\hline 10 & -6.47 & $-209 \%$ & -22.28 & $-190 \%$ & 30.73 & $5 \%$ \\
\hline 20 & -16.55 & $-215 \%$ & -33.80 & $-206 \%$ & 28.47 & $4 \%$ \\
\hline 30 & -26.63 & $-218 \%$ & -45.31 & $-210 \%$ & 26.20 & $4 \%$ \\
\hline 40 & -36.71 & $-220 \%$ & -56.83 & $-213 \%$ & 23.93 & $3 \%$ \\
\hline \multicolumn{7}{|c|}{ Central South Region } \\
\hline-40 & -37.11 & $8 \%$ & -54.35 & $8 \%$ & 44.94 & $6 \%$ \\
\hline-30 & -56.67 & $8 \%$ & -76.78 & $7 \%$ & 43.17 & $6 \%$ \\
\hline-20 & -76.23 & $7 \%$ & -99.21 & $7 \%$ & 41.41 & $6 \%$ \\
\hline-10 & -95.78 & $6 \%$ & -121.64 & $6 \%$ & 39.64 & $5 \%$ \\
\hline 0 & -115.34 & $5 \%$ & -144.06 & $5 \%$ & 37.87 & $5 \%$ \\
\hline 10 & -134.89 & $4 \%$ & -166.49 & $4 \%$ & 36.10 & $5 \%$ \\
\hline 20 & -154.45 & $2 \%$ & -188.92 & $3 \%$ & 34.33 & $4 \%$ \\
\hline 30 & -174.01 & $1 \%$ & -211.35 & $1 \%$ & 32.57 & $4 \%$ \\
\hline 40 & -193.56 & $-2 \%$ & -233.78 & $-1 \%$ & 30.80 & $4 \%$ \\
\hline
\end{tabular}




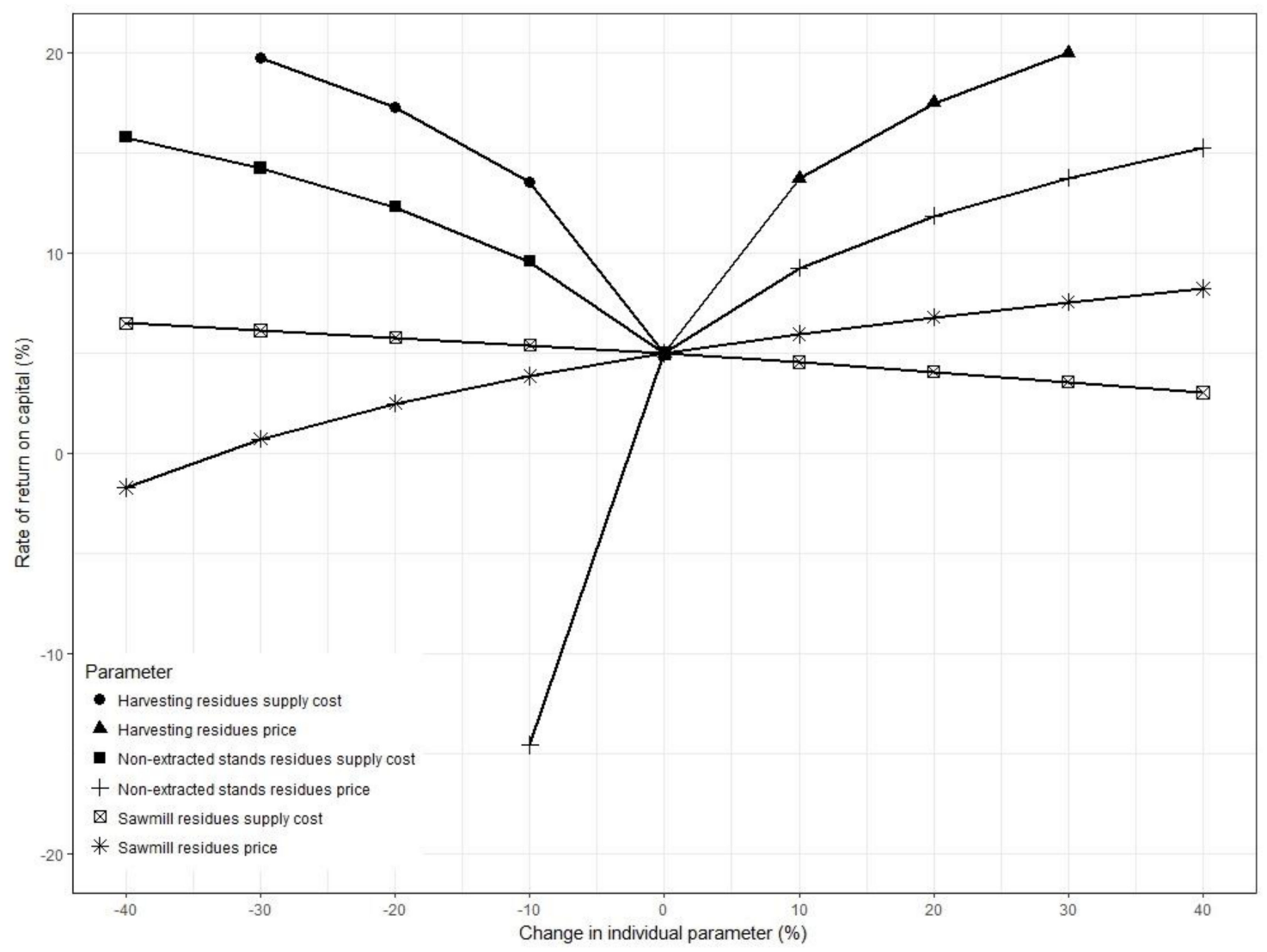

Figure 2. Sensitivity analysis of percentage variation of the most probable estimate for the northern region. Note: Values beyond $-20 \%$ and $20 \%$ on the $y$ axis are not shown in the graph.

Figure 3 shows the response curve of the ROC for the central south region. Results presented the lowest sensitivity to the ROC in the parameters harvesting residues price and non-extracted stands residues price. In contrast, the parameter sawmill residues price demonstrated the highest sensitivity to the ROC. It is important to note that for the sources harvesting residues and non-extracted stand residues from the central south region, the economic flow based on a status quo is negative (see Tables 5-7). Further analysis for recommendations is required.

With respect to the central south region, values from harvesting residues and non-extracted stand residues had a negative output. Nevertheless, results from the sensitivity analysis showed a considerable sensitivity to changes to cost for these two biomass sources. That is to say, when decreasing the supply cost of utilizing forest woody biomass residues by up to $10 \%$, an ROC of at least $6 \%$ will result. This challenging cost reduction can be achieved through improvement of the flow within the supply chain based on techniques and systems for resource management such as enterprise resource planning (ERP) among others. It is critical to note that only stand residues sourced from non-extracted stands were taken into account for the economic analysis. Industrial round wood was used for higher value added products rather than for biomass for energy use. If round wood from non-extracted stands had also been considered, the analysis for this source would have greater values for the northern region and positive values for the central south. Differences between the two analyzed regions in relation to prices, costs and revenues were observed, where prices higher than the one observed in the status quo and balancing cost on both regions could have positive impact for the introduction of bioenergy markets considering forest woody biomass residues. Table 8 summarizes the highest expected values for each parameter, for each source and for both regions. 


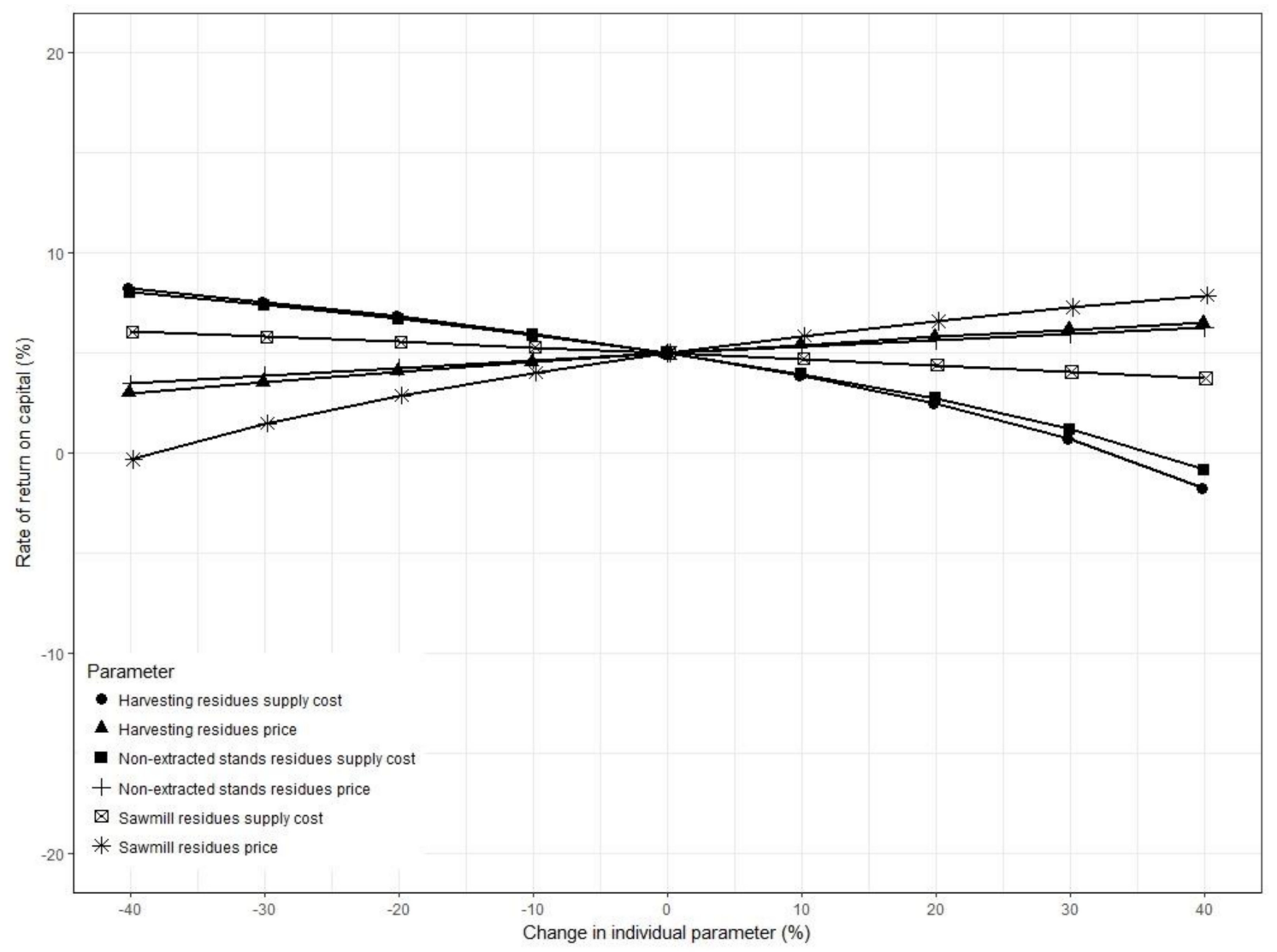

Figure 3. Sensitivity analysis of percentage variation of the most probable estimate for the central south region. Note: Values beyond $-20 \%$ and $20 \%$ on the $y$ axis are not shown in the graph.

Table 8. Highest expected values and ROC for each parameter, for each source and for both analyzed regions.

\begin{tabular}{|c|c|c|c|c|}
\hline \multirow[b]{2}{*}{ Region/Biomass Source } & \multicolumn{2}{|l|}{ Price } & \multicolumn{2}{|l|}{ Cost } \\
\hline & Net Future Value (USD/m ${ }^{3}$ ) & ROC & Net Future Value (USD/m ${ }^{3}$ ) & ROC \\
\hline \multicolumn{5}{|l|}{ North } \\
\hline Harvesting residues & 45.36 & $22 \%$ & 43.92 & $22 \%$ \\
\hline Non-extracted stand residues & 30.99 & $15 \%$ & 35.30 & $16 \%$ \\
\hline Sawmill residues & 55.26 & $8 \%$ & 42.06 & $7 \%$ \\
\hline \multicolumn{5}{|l|}{ Central South } \\
\hline Harvesting residues & -83.24 & $7 \%$ & -37.11 & $8 \%$ \\
\hline Non-extracted stand residues & -111.97 & $6 \%$ & -54.34 & $8 \%$ \\
\hline Sawmill residues & 60.09 & $8 \%$ & 44.94 & $6 \%$ \\
\hline
\end{tabular}

\section{Discussion}

As new developments in the bioenergy sector are influenced by biomass availability tempered by social, ecological, and economic constraints, more studies regarding forest utilization and analysis of economic alternatives are required to support decision-making processes for regional bio-economies. Thus, this paper aimed to evaluate economic alternatives for utilizing forest residues based on stochastic simulation to assess the changes to economic parameters within a given time frame. The first step was to estimate costs and treat uncertainties due to differences between regions using the Monte Carlo method.

Regarding the cost category, a comparison of the estimated means from the 27 sampled enterprises, revealed that the greatest difference between regions was the cost of workforce (labor cost and labor 
cost from machine operation), where the mean for the central south region was almost double that of the north. For both regions, transportation costs made up the greatest cost share of the total cost of utilizing forest woody biomass. This difference could be explained by the fact of owning or renting the equipment for transportation, distances between forest and final destination, low integration between forest areas and transformation centers and poor conditions of road infrastructure in the central south region. The small share of road construction costs was related to high transportation costs. The low investment in road construction results in poor conditions of infrastructure for transportation.

Moreover, all the analyzed costs were higher in the central south region; with the exception of operation and maintenance costs from sawmill processing. This can be explained based on the development and robust integration between actors and stakeholders in the northern region. This involves availability of equipment, forest labor and know-how regarding utilization. As shown in Table 2, the range between minimum and maximum values was high, which indicates variability among the sampled universe in terms of management and utilization. Differences and variability in costs between regions was mainly due to harvesting levels between CFEs and regions, the efficiency of each CFE and updated data from the sampled CFEs.

After costs were stochastically simulated and an NFV analysis was carried out, supply costs and timber prices were related in a sensitivity analysis to estimate changes to ROC using the parameter cost and price within a time frame of 17 years. Based on results, approaches and strategies focused on prices will have positive repercussions for the market resulting in an ROC of at least $6 \%$, compared to $5 \%$ from balancing costs. Moreover, lowering costs through an integration of the stakeholders along the supply chain, applying programs for sustainable funding and cooperation between forest enterprises, government and local authorities will open opportunities to boost timber markets and develop solid bioenergy markets. As mentioned before, this scenario is based on an interest rate of $5 \%$ as a conservative rate. Generally in Mexico, a discount rate of $12 \%$ is used when evaluating public investment projects. However, when midterm projects are evaluated, low rates are recommended [37].

Considering the estimated outputs from the northern region, results demonstrated similar sensitivity to prices and cost of the biomass sources harvesting residues and non-extracted stand residues. Thus, developing strategies to decrease cost or increase price within a range of $-40 \%$ to $40 \%$ will have a similar output. The parameters price and cost of harvesting residues also represented the highest sensitivity in comparison to cost and prices from non-extracted stand residues and sawmill residues. However, these results only considered residues as the main byproduct for the economic analysis. No industrial round wood was included as a product. A scenario based on the utilization of industrial round wood in addition to harvested stands from non-extracted stands will have additional positive impacts on the economic output.

Furthermore, maintaining supply costs from the year 2013 and improving prices between $5 \%$ and $7 \%$ within the analyzed timeframe, resulted in a total revenue contribution of $9.83 \mathrm{USD} / \mathrm{m}^{3}$. On the other hand, reducing costs up by to $10 \%$ will increase the ROC to $14 \%, 10 \%$ and $5 \%$ for harvesting residues, non-extracted stands and sawmill residues respectively (see Table 7). As shown in Table 2, transportation costs are the highest among the two regions, with a total share of $36 \%$ of the total supply cost in the northern region. A reduction of this cost based on improved logistics, infrastructure upgrading of roads through public funding, and other approaches such as consolidating shipments could lead to a $10 \%$ reduction in transportation costs. Moreover, actions based on the extension of sustainably managed forests appear as a latent strategy for developing a biomass market in the northern region in the long term. This also includes the introduction of advanced forest operations that would not only impact machine and labor cost but also improve biomass availability (Table 9). As markets for renewable energies are becoming more important in Mexico, strategies based on prices will play an important role. According to information from the Program for the Development of the National Electric System 2017-2031 (Programa de Desarrollo del Sistema Eléctrico Nacional 2017-2031), in Mexico [38] there is a planned investment of 119.41 million USD in infrastructure over the next 15 years for energy projects, which includes 16 wind power and solar plants. This would ease the 
introduction of new renewable energy supply chains, impacting revenues and costs while supporting actions based on price for harvesting residues and non-extracted stand residues in the long term (Table 9).

On the other hand, the analysis for the central south region showed higher costs in comparison to the northern region, where biomass sourced from harvesting residues and non-extracted stand residues made a negative contribution to profit. Similar to the pattern of harvesting residues for the northern region, the parameter price from the sawmill residues in the central south region showed the highest sensitivity to changes (Figure 3). Based on results from Tables 6 and 7, for the biomass sources harvesting residues and non-extracted stand residues, setting strategies for decreasing cost through an efficient material flow, for instance planning and exploiting bottlenecks within the supply chain, would impact profit contribution. In the short to mid-term, a strategy based on revenues from sawmill residues to invest in road construction as well as capacity building in the workforce and forest operations would support biomass availability from harvesting residues and non-extracted stand residues, thus impacting cost and price. In the long term, a similar approach of extending sustainably managed forests in the northern region is recommended.

Table 9. Recommendations according to time frame and analyzed regions.

\begin{tabular}{ll}
\hline \multicolumn{1}{c}{ Short Term to Mid-Term (5-30 Years) } & \multicolumn{1}{c}{ Long Term (31-50 Years) } \\
\hline \multicolumn{1}{c}{ North } & \\
\hline $\begin{array}{l}\text { - A 10\% reduction in the transportation cost is } \\
\text { recommended in order to reduce overall supply costs, } \\
\text { resulting in a total revenue of } 13.69 \text { USD } / \mathrm{m}^{3} \text { and }\end{array}$ & $\begin{array}{l}\text { - An extension of sustainably managed forests is } \\
\text { recommended and expected within the next } 50 \text { years. }\end{array}$ \\
$\begin{array}{l}\text { 0.75 USD } / \mathrm{m}^{3} \text { for harvesting residues and } \\
\text { non-extracted stand residues, respectively. }\end{array}$ & $\begin{array}{l}\text { This would result in increased biomass availability } \\
\text { and therefore a possible cost reduction of } 20 \%,\end{array}$ \\
- For non-extracted stand residues, cost reduction & amounting to 23.77 USD $/ \mathrm{m}^{3}$ and $12.27 \mathrm{USD} / \mathrm{m}^{3}$ for \\
through improved logistics is also recommended. & harvesting residues and non-extracted stands \\
- Actions focused on setting prices between $5 \%$ and & residues, respectively. \\
$\begin{array}{l}\text { 7\% of the status quo supported by governmental } \\
\text { investments are recommended. }\end{array}$ & \\
\hline
\end{tabular}

\section{Central South}

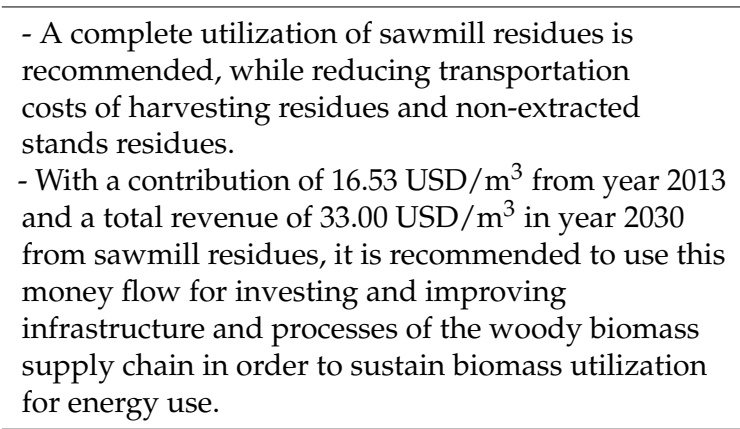

As mentioned before, supply costs and revenues of biomass for energy use were assumed to be a plus for the CFEs, thus other related costs within the timber supply chain, such as machine costs, were assumed to be already accounted for and were not included in the analysis. Based on the results, while focusing on extending sustainably managed forests in the long-term, a strategy focused on reducing transportation costs and using revenues from sawmill residues to invest in road construction and infrastructure for both regions in the short-term and mid-term is recommended

In addition to the mentioned recommendations, with the given output from the sensitivity analysis of percentage variation of the most probable estimate, combinations of changes in price and cost for the mid-term can be calculated. These combinations are shown in Table 10 in terms of ranges and the highest contribution for each biomass source and region. In order to simulate results in an optimal way, conservative rates for the changes in the parameters were used. 
Table 10. Recommended combinations of changes in price and cost with the highest revenue contribution in the mid-term.

\begin{tabular}{cccc}
\hline & & Biomass Source & \\
\hline Region & Harvesting Residues & Non-Extracted Stands Residues & Sawmill Residues \\
\hline \multirow{3}{*}{ North } & $\begin{array}{c}\uparrow \text { Price in a range of }[5-10 \%] \\
\text { and } \downarrow \text { cost in a range of } \\
{[1-10 \%]=24.12 \text { USD } / \mathrm{m}^{3}}\end{array}$ & $\begin{array}{c}\uparrow \text { Price in a range of }[5-10 \%] \text { and } \downarrow \text { cost } \\
\text { in a range of }[1-10 \%]=11.19 \text { USD } / \mathrm{m}^{3}\end{array}$ & $\begin{array}{c}\uparrow \text { Price in a range of [5-10\%] } \\
\text { and } \downarrow \text { cost in a range of } \\
{[1-10 \%]=40.82 \text { USD } / \mathrm{m}^{3}}\end{array}$ \\
\hline \multirow{5}{*}{ Central South } & $\begin{array}{c}\downarrow \text { Transportation cost in a } \\
\text { range of [1-10\%] and use } \\
\text { money flow from sawmill } \\
\text { residues for investment }\end{array}$ & $\begin{array}{c}\downarrow \text { Transportation cost in ange of } \\
{[1-10 \%] \text { and use money flow from }} \\
\text { sawmill residues for investment }\end{array}$ & $\begin{array}{c}\uparrow \text { Price up to } 5 \% \text { and } \downarrow \text { cost to } \\
5 \%=45.19 \text { USD } / \mathrm{m}^{3}\end{array}$ \\
\hline
\end{tabular}

Due to the number of different strategies and combinations, ranges were used accounting to the highest value within this range as a highest contribution.

These strategies and combinations depend on several factors that could determine the future economic flow and economic alternatives within the Mexican forest context, for instance the development of forest plantation projects. According to the National Forestry Council, there are 22 million hectares available in Mexico for developing commercial plantation projects, of which 13.9 million ha have been identified as priority areas due to their good soil quality, favorable weather conditions, and available workforce [39]. The report "Costos y Beneficios de Diferentes Tipos de Uso de Suelo en México" ("Cost and Benefits of Different Types of Land Use in Mexico") [38] presents a feasibility analysis regarding the cost of several land use options, in which commercial plantations are rated as the second highest cost-benefit index amongst all analyzed options [38]. Moreover, this report finds a net profit of $\$ 15,914,910.00 \mathrm{MXN}(1,218,599.54 \mathrm{USD})$ with a discount rate of $12 \%$ coming from forest utilization in a 100 ha area for mahogany and a time horizon of 60 years as a land use option. Out of eight land use alternatives in Mexico, forest utilization and commercial forest plantations have high cost-benefit indices of 0.57 and 2.24, respectively, meaning economic potential for their development [37].

Thus, considering biomass availability identified through scenario modeling given an increment of timber production areas and restricted by sustainability constraints, together with the sensitivity analysis presented in this paper, economic alternatives can be identified for the decision-making process. It is important to note that previous studies involving forest utilization, like that developed by Lara et al. [37], were restricted to analyses of economic outputs accounting for timber production. In contrast, this paper evaluates forest woody biomass residues for bioenergy as an economic option with considerable potential for development that has not yet been fully studied.

In a comparison of Latin-American countries, based on a study developed by Cubbage et al., [40] standing timber prices from Chile, Brazil, Argentina, Uruguay, Colombia, Venezuela and Paraguay were lower than the Mexican standing timber prices. On the other hand, harvesting costs were also lower. When comparing revenues from these countries, there was a minimum value of $6.78 \mathrm{USD} / \mathrm{m}^{3}$, a maximum of $30.60 \mathrm{USD} / \mathrm{m}^{3}$ and a mean of $19.09 \mathrm{USD} / \mathrm{m}^{3}$. However, despite the higher costs and higher prices observed in Mexico, the revenues identified in the present research suggest opportunities for the development of energy supply chains based on forest woody biomass predominantly in the northern region.

With the introduction of the General Law of Climate Change and the National Climate Change Strategy [41], the development of alternative energy supply chains based on sustainability parameters is crucial at regional and national levels. Guevara et al. [24] argued that further research on energy supply and its evolution in Mexico should be focused on understanding the relationship between energy and economics and evaluating the impact of energy policies on the energy and economy sectors. As suggested by the International Energy Agency, the introduction of methodologies and sustainability criteria for bioenergy supply-chain use and forecasting different medium- and long-term demand scenarios are fundamental to achieving the main objectives of the law together with actions presented 
in the National Climate Strategy [42]. The presented results from this research contribute to this purpose by modeling economic outputs in the short to long term scenarios based on sustainability criteria for achieving goals within climate change strategies.

The creation of forest wood supply chains opens up a range of opportunities for supplying biomass to the bio-economy, with bioenergy as an alternative value chain. The forest sector in Mexico is challenging and under development where economic profitability could be achieved throughout the application of programs guided by the implementation of policies, capacity building, market development and integration of the stakeholders involved in the value chain. The offered opportunities, such as energy transformation, are strengthened with the creation of supply chains and the diversification of products. The implications of this research consider the design of sustainability guidelines that affect decision-making processes regarding energy policies and forest management plans.

Further research advancements involve the collection of more significant data regarding costs and revenues from forest woody biomass utilization at a local level to create regional datasets that include a representative sampling universe for modeling accurate simulations. This would set the basis to give recommendations considering business models for the forestry and energy industries according to regional conditions such as species, terrain conditions, equipment, forest logistics and energy demand. Moreover, the development of models that assess forest woody biomass availability for energy use together with the evaluation of economic alternatives for wood energy supply within a time horizon is a fundamental factor for the research progress.

Research constraints such as: data availability considering forestry business models, lack of economic and technical studies considering forest woody biomass for energy use and the low given attention to the forest sector for climate mitigation strategies at a national level, were challenges this study identified.

Advanced forest operations and forest management together with business strategies are essential aspects for improving the industry towards the development of a national bio-economy. The outputs presented in this paper support recommendations for each of the analyzed regions regarding economic alternatives based on changes in price and costs and their effects on the rate of return of capital. These results provide the basis for the decision-making process regarding forest utilization towards energy generation based on economic indicators.

\section{Conclusions}

This research involves evaluating the opening of bioenergy markets in Mexico, by estimating alternative costs and prices of utilizing the analyzed residues for energy use. The aim was to simulate changes in the economic parameters within a given time frame to evaluate the potential of introducing energy supply chains based on forest woody biomass at a regional level. In order to carry out this evaluation, a methodology framework involving Monte Carlo simulations and sensitivity analyses of percentage variation of the most probable estimate was conducted. This included an assessment of the percentage change of the parameters cost and price against the rate of return on capital (ROC) when individual parameters increase or decrease within a range. The analysis was developed for three biomass sources (harvesting residues, non-extracted stand residues, and sawmill residues) for both regions. With the given results, an evaluation of one alternative with changes to several parameters within a specific time series can be graphically presented, making the decision-making process clearer. Moreover, the opening up of the bioenergy market based on forest woody biomass residues can be modeled from several perspectives when analyzing variables such as price, cost and ROC.

Given the presented results, a focus on investing in energy supply chains based on forest woody biomass in the short to mid-term is recommended in the northern region. This is based on the high sensitivity observed in the parameters price and cost for the biomass sources harvesting residues and non-extracted stand residues. Moreover, due to the integration along the value chain in this region and based on the introduction of more diverse renewable energy supply chains, energy markets will 
be affected supporting prices and costs in the long-term. Furthermore, based on simulations, a $10 \%$ reduction in the transportation cost would reduce overall supply cost, resulting in total revenues of $13.69 \mathrm{USD} / \mathrm{m}^{3}$ and $0.75 \mathrm{USD} / \mathrm{m}^{3}$ for harvesting residues and non-extracted stand residues, respectively. For the central south region, results identified a negative economic flow with the exception of sawmill residues. A contribution of $16.53 \mathrm{USD} / \mathrm{m}^{3}$ from the year 2013 and a total revenue of $33.00 \mathrm{USD} / \mathrm{m}^{3}$ in 2030 from sawmill residues are estimated to improve the value chain. A focus on the improvement of the harvesting value chain supported by revenues from sawmill residues is recommended.

Strategies for estimating positive economic outputs result when modeling alternatives such as increment of areas for timber production and the introduction of advanced forest techniques [43]. With this, balancing prices and costs according to forest woody biomass availability affects decision-making regarding the opening up of bioenergy markets. Moreover, the economic impact of decreasing timber imports can be evaluated in light of scenario modeling and the presented analysis.

Studies and research regarding sustainable forest management practices, the introduction of advanced forest operations and economic models for developing regional bioenergy markets are fundamental for a transition from a fossil-based economy. The potential offered by the Mexican forest, as a major biomass supplier, could alleviate socioeconomic deficiencies and also mitigate environmental impacts. This study gives basis for evaluating economic alternatives regarding energy markets based on forest woody biomass, contributing to the decision-making processes for developing a bio-economy at a regional level in Mexico.

Modeling different scenarios regarding an increment of production areas and the introduction of advanced forest operations will impact forest woody biomass availability, affecting economic alternatives for developing bioenergy markets, too. For instance, based on numerical modelling with sustainability constraints as limits for biomass production [43], a conservative increment of the mechanization level amounts to 976.98 million MXN of GDP for 2030 from forest woody biomass for energy use, compared to 38.05 million MXN observed in 2014. Under the assumption of applying advanced techniques of forest operations the sustainable supply of energy from woody biomass could be increased by $12 \%$ to $44.55 \mathrm{PJ}$ by the year 2030 compared to $44.32 \mathrm{PJ}$ for a status quo scenario [43]. Given these alternatives, new perspectives for the opening up of bioenergy markets in Mexico can be analyzed, lowering costs due to higher availability and also impacting the balance of prices.

Acknowledgments: This research project was supported by the Deutscher Akademischer Austauschdienst (DAAD) as part of the scholarship program Forschungsstipendien für Doktoranden und Nachwuchswissenschaftler für mehr als 6 Monate, 2014/15 (57048249). The article processing charge was funded by the German Research Foundation (DFG) and the University of Freiburg in the funding program Open Access Publishing.

Author Contributions: Ulises Flores Hernández conceived and designed the experiments, performed the experiments, and analyzed the data; Dirk Jaeger and Jorge Islas Samperio contributed reagents/materials/analysis tools; Ulises Flores Hernández wrote the paper.

Conflicts of Interest: The authors declare no conflict of interest. The founding sponsors had no role in the design of the study; in the collection, analyses, or interpretation of data; in the writing of the manuscript, and in the decision to publish the results.

\section{References}

1. McKendry, P. Energy production from biomass (part 1): Overview of biomass. Bioresour. Technol. 2002, 83, 37-46. [CrossRef]

2. Chum, H.; Faaij, A.; Moreira, J.; Berndes, G.; Dhamija, P.; Kingdom, U. Bioenergy. In IPCC Special Report on Renewable Energy Sources and Climate Change Mitigation; IPCC: Geneva, Switzerland, 2012; Chapter 2, pp. 209-332. Available online: http://www.ipcc.ch/pdf/special-reports/srren/Chapter2Bioenergy.pdf (accessed on 12 April 2018).

3. IRENA. Renewable Energy Technologies: Cost Analysis Series. Biomass Power Gener. 2012, 1, 60.

4. World Energy Council. World Energy Resources Bioenergy 2016; World Energy Council: London, UK, 2016; Volume 60. 
5. Carneiro, P.; Ferreira, P. The economic, environmental and strategic value of biomass. Renew. Energy 2012, 44, 17-22. [CrossRef]

6. Teske, S.; Fattal, A.; Lins, C.; Hullin, M.; Williamson, L.E. Renewables Global Futures Report: Great Debates towards 100\% Renewable Energy; IAEA: Paris, France, 2017.

7. Strzalka, R.; Schneider, D.; Eicker, U. Current status of bioenergy technologies in Germany. Renew. Sustain. Energy Rev. 2017, 72, 801-820. [CrossRef]

8. Smith, P.; Bustamante, M. Agriculture, forestry and other land use. In Climate Change 2014: Mitigation of Climate Change; Cambridge University Press: Cambridge, UK, 2014.

9. Koppejan, J.; Van Loo, S. (Eds.) The Handbook of Biomass Combustion and Co-Firing; Earthscan: London, UK, 2012.

10. McKendry, P. Energy production from biomass (part 2): Conversion technologies. Bioresour. Technol. 2002, 83, 47-54. [CrossRef]

11. McDermott, S.M.; Howarth, R.B.; Lutz, D.A. Biomass energy and climate neutrality: The case of the northern forest. Land Econ. 2015, 91, 197-210. [CrossRef]

12. Van Kooten, G.C.; Johnston, C.M.T. The Economics of Forest Carbon Offsets. Ann. Rev. Resour. Econ. 2016, 8, 227-246. [CrossRef]

13. Comisión Nacional Forestal CONAFOR. Inventario Nacional Forestal y de Suelos. Informe 2004-2009; Comisión Nacional Forestal CONAFOR: Jalisco, Mexico, 2012. Available online: http:/ /www.ccmss.org.mx/ descargas/Inventario_nacional_forestal_y_de_suelos_informe_2004_-_2009_pdf (accessed on 12 April 2018).

14. Comisión Nacional Forestal CONAFOR. Información Estadística de la Producción Forestal Nacional 2015; Comisión Nacional Forestal CONAFOR: Jalisco, Mexico, 2015. Available online: http:/ /www.cnf.gob.mx: 8090/snif/portal/economica/estadistica-forestal-nacional (accessed on 12 April 2018).

15. Puente González, A. Segunda Revisión del Programa Estratégico Forestal para México 2025 y del Programa Nacional Forestal 2001-2006; Competitividad del Sector Forestal de México Tendencias y Perspectivas; Comisión Nacional Forestal CONAFOR: Jalisco, Mexico, 2009; Food and Agricultural Organization FAO: Rome, Italiy, 2009.

16. Torres, J. Estudio de Tendencias y Perspectivas del Sector Forestal en América Latina Documento de Trabajo; Informe Nacional México; Food and Agricultural Organization FAO: Rome, Italiy, 2004.

17. Instituto Nacional de Investigaciones Forestales Agrícolas y Pecuarias INIFAP. Determinación del Potencial y Aprovechamiento de los Residuos Forestales en la Producción de Bioenergía y de Especies no Aprovechadas en el Manejo Forestal; Instituto Nacional de Investigaciones Forestales, Agrícolas y Pecuarias INIFAP: Mexico City, Mexico, 2012.

18. Ávila, A. Análisis de Producción y Costos de las Operaciones de Abastecimiento en la Unidad de Administración Forestal No.2 Valle de Bravo, Estado de México; Universidad Autónoma Chapingo: Texcoco, Mexico, 1983.

19. Comisión Nacional Forestal CONAFOR. Evaluación de Costos de Extracción y Abastecimiento de Productos de Plantaciones Forestales Comerciales; Comisión Nacional Forestal CONAFOR: Jalisco, Mexico, 2011.

20. García, C.; Riegelhaupt, E.; Ghilardi, A.; Skutsch, M.; Islas, J.; Manzini, F.; Masera, O. Sustainable bioenergy options for Mexico: GHG mitigation and costs. Renew. Sustain. Energy Rev. 2015, 43, 545-552. [CrossRef]

21. Rios, M.; Kaltschmitt, M. Bioenergy potential in Mexico-status and perspectives on a high spatial distribution. Biomass Convers. Biorefinery 2013, 3, 239-254. [CrossRef]

22. Islas, J.; Manzini, F.; Masera, O. A prospective study of bioenergy use in Mexico. Energy 2006, 32, $2306-2320$. [CrossRef]

23. Secretaría de Medio Ambiente y Recursos Naturales SEMARNAT. Anuarios Estadísticos de la Producción Forestal 1993-2014; Secretaría del Medio Ambiente y Recursos Naturales SEMARNAT: Mexico City, Mexico, 2015. Available online: http://www.semarnat.gob.mx/temas/gestion-ambiental/forestal-y-suelos/anuariosforestales (accessed on 12 April 2018).

24. Guevara, Z.; Córdoba, O.; García, E.X.M.; Bouchain, R. The Status and Evolution of Energy Supply and Use in Mexico Prior to the 2014 Energy Reform: An Input-Output Approach. Economies 2017, 5, 10. [CrossRef]

25. EIA. Petroleum and Other Liquids; U.S. Energy Information Administration: Washington, DC, USA, 2016.

26. Poder Ejecutivo Federal, National Strategic Plan for Development 2007-2012. Available online: http:/ / pnd. calderon.presidencia.gob.mx/pdf/PND_2007-2012.pdf (accessed on 12 April 2018).

27. Alemán-Nava, G.; Meneses-Jácome, A.; Cárdenas-Chávez, D.; Díaz-Chavez, R.; Scarlat, N.; Dallemand, J.; Ornelas-Soto, N.; García-Arrazola, R.; Parra, R. Bioenergy in Mexico: Status and perspective. Biofuels Bioprod. Biorefin. 2015, 9, 8-20. [CrossRef]

28. Sacchelli, S.; Zambelli, P.; Zatelli, P.; Ciolli, M. Biomasfor: An open-source holistic model for the assessment of sustainable forest bioenergy. iFor. Biogeosci. For. 2013, 6, 285-293. [CrossRef] 
29. Schelhaas, M.J.; van Esch, P.W.; Groen, T.A.; de Jong, B.H.J.; Kanninen, M.; Liski, J.; Masera, O.; Mohren, G.M.J.; Nabuurs, J.; Palosuo, T.; et al. CO2FIX V 3.1-A Modelling Framework for Quantifying Carbon Sequestration in Forest Ecosystems; ALTERRA: Wageningen, The Netherlands, 2004.

30. Sokhansanj, S.; Kumar, A.; Turhollow, A.F. Development and implementation of integrated biomass supply analysis and logistics model (IBSAL). Biomass Bioenergy 2006, 30, 838-847. [CrossRef]

31. Masera, O.; Guerrero, G.; Ghilardi, A.; Velázquez, A.; Mas, J.; Ordoñez, M.D.J.; Drigo, R.; Trossero, M.A. Fuelwood "Hot Spots" in Mexico: A Case Study Using WISDOM-Woodfuel Integrated Supply-Demand Overview Mapping; Food and Agriculture Organization: Rome, Italy, 2004.

32. Sansaniwal, S.K.; Pal, K.; Rosen, M.A.; Tyagi, S.K. Recent advances in the development of biomass gasification technology: A comprehensive review. Renew. Sustain. Energy Rev. 2017, 72, 363-384. [CrossRef]

33. Diario Oficial de la Federación. Available online: http://www.dof.gob.mx/indicadores.php (accessed on 12 April 2018).

34. Cubbage, F.; Davis, R.; Rodríguez, D.; Frey, G.; Mollenhauer, R.; Kraus, Y.; González, I.; Albarrán, H.; Salazar, A.; Chemor, D. Competitividad y Acceso a Mercados de Empresas Forestales Comunitarias en México; Programa Sobre los Bosques PROFOR: Mexico City, Mexico, 2013.

35. Maarit, A.; Kallio, I. Accounting for uncertainty in a forest sector model using Monte Carlo simulation. For. Policy Econ. 2010, 12, 9-16. [CrossRef]

36. Blank, L.T.; Tarquin, A.J. Engineering Economy, 5th ed.; McGraw-Hill Series in Industrial Engineering and Management Science; McGraw-Hill: New York, NY, USA, 2002.

37. Lara, J.; Guevara, A.; Alba, R. Costos y Beneficios de Diferentes Tipos de Uso de Suelo en México; Agencia de los Estados Unidos para el Desarrollo Internacional (USAID): Mexico City, Mexico, 2014.

38. Secretaría de Energía. Programa de Desarrollo del Sistema Eléctrico Nacional 2017-2031; Secretaría de Energía: Mexico City, Mexico, 2016. Available online: http://base.energia.gob.mx/prodesen/PRODESEN2017/ PRODESEN-2017-2031.pdf (accessed on 12 April 2018).

39. Comisión Nacional Forestal CONAFOR. Programa Estratégico Forestal para México 2025; Comisión Nacional Forestal CONAFOR: Jalisco, Mexico, 2001. Available online: http://era-mx.org/biblio/PEF_2025.pdf (accessed on 12 April 2018).

40. Cubbage, F.; Koesbandana, S.; Mac Donagh, P.; Rubilar, R.; Balmelli, G.; Morales Olmos, V.; De La Torre, R.; Murara, M.; Hoeflich, V.A.; Kotze, H.; et al. Global timber investments, wood costs, regulation, and risk. Biomass Bioenergy 2010, 34, 1667-1678. [CrossRef]

41. Secretaría de Medio Ambiente y Recursos Naturales SEMARNAT. National Climate Change Strategy 10-20-40 Vision; Secretariat of Environment and Natural Resources-Sub-Secretariat of Planning and Environmental Policy, General Direction of Climate Change Policies, Government of the Republic “Estados Unidos Mexicanos": Mexico City, Mexico, 2013.

42. Eisentraut, A. The Biofuel and Bioenergy Roadmaps of the International Energy Agency. In Bioenergy and Water; JRC Technical Report EUR 26160 EN; European Commission: Ispra, Italy, 2013.

43. Flores Hernández, U.; Jaeger, D.; Islas Samperio, J. Bioenergy Potential and Utilization Costs for the Supply of Forest Woody Biomass for Energetic Use at a Regional Scale in Mexico. Energies 2017, 10, 1192. [CrossRef]

(C) 2018 by the authors. Licensee MDPI, Basel, Switzerland. This article is an open access article distributed under the terms and conditions of the Creative Commons Attribution (CC BY) license (http://creativecommons.org/licenses/by/4.0/). 